\title{
Disseminated herpes simplex virus type 1 primary infection in a healthy individual
}

\author{
Guy Boivin $\mathrm{MD}^{1,2}$, Brigitte Malette $\mathrm{PhD}^{3}$, Nathalie Goyette MSc ${ }^{1}$
}

\begin{abstract}
G Boivin, B Malette, N Goyette. Disseminated herpes simplex virus type 1 primary infection in a healthy individual. Can J Infect Dis Med Microbiol 2009;20(4):122-125.
\end{abstract}

BACKGROUND: Primary herpes simplex virus (HSV) infection usually involves one mucosal region.

OBJECTIVE: To describe an unusual disseminated HSV-1 infection involving two mucosal sites in a healthy man.

RESULTS: Primary HSV infection involved oral and genital mucosa and was associated with viremia, hepatitis and rash. Phylogenetic analysis of genital and oral viruses revealed that the patient was infected by a single HSV-1 strain.

CONCLUSION: Use of polymerase chain reaction detection techniques for HSV may identify viremic patients in the absence of obvious immunosuppression.

Key Words: Dissemination; Herpes simplex virus; Immunocompetent; PCR; Viremia

\section{Une infection disséminée par le virus de l'herpès simplex de type $1 \mathrm{chez}$ une personne en santé}

\begin{abstract}
HISTORIQUE : L'infection primaire par le virus de l'herpès simplex (VHS) touche généralement un foyer muqueux. OBJECTIF : Décrire une infection disséminée par le VHS-1 inhabituelle touchant deux foyers muqueux chez un homme en santé.

RÉSULTATS : L'infection primaire par le VHS touchait les muqueuses orale et génitale et s'associait à une virémie, à une hépatite et à une éruption. L'analyse phylogénétique des virus génital et oral a révélé que le patient était infecté par une seule souche du VHS-1.

CONCLUSION : Les techniques de détection par la réaction en chaîne de la polymérase pour le VHS peuvent permettre de dépister les patients virémiques en l'absence d'immunosuppression évidente.
\end{abstract}

\begin{abstract}
Drimary herpes simplex virus (HSV) infection in immunocompetent subjects usually involves one mucosal site although systemic and sometimes meningeal symptoms can be present. We report an unusual case of disseminated primary HSV type 1 (HSV-1) infection in a healthy man involving the oral and genital areas associated with documented viremia. In addition, our patient had hepatitis and a rash probably related to HSV-1.
\end{abstract}

\section{CASE PRESENTATION}

A 33-year-old man consulted at the emergency room of a tertiary care hospital for fever, dysuria and sore throat in November 2007. He had no pertinent antecedents or allergies. He was not usually on any medication but he had been taking levofloxacin $500 \mathrm{mg}$ once daily for two days for a presumptive urinary tract infection. His dysuria had started two days previously followed by fever and a sore throat the following day. He was also complaining of myalgia and fatigue for the past $24 \mathrm{~h}$. On admission, he denied recent travel, new sexual partner or intravenous drug use. Upon examination, the patient appeared ill and rectal temperature was $39.2^{\circ} \mathrm{C}$. He had a pharyngeal hyperhemia with no ulcers observed at that time. Similarly, no vesicles, ulcers or discharge were noted on the penis and the perianal region. There was no rash and the rest of the physical examination was normal. Initial laboratory testing revealed a white blood count of $9.3 \times 10^{9} / \mathrm{L}$ with a lymphopenia $\left(0.5 \times 10^{9} / \mathrm{L}\right)$, sedimentation rate of $16 \mathrm{~mm} / \mathrm{h}$, increased hepatic transaminases (aspartate aminotransferase $146 \mathrm{U} / \mathrm{L}$, alanine aminotransferase $270 \mathrm{U} / \mathrm{L}$ and gammaglutamyltransferase $307 \mathrm{U} / \mathrm{L}$ ), negative mononucleosis test for heterophil antibodies, normal urine examination, and negative direct immunofluorescence tests for adenoviruses and influenza $A$ and $B$ viruses on a nasopharyngeal aspirate. The patient was admitted with a diagnosis of unspecified viremia and levofloxacin was stopped on that day. Blood, urine and throat bacterial cultures were performed and a urine sample was collected for detection of Chlamydia trachomatis and Neisseria gonorrhoeae by polymerase chain reaction (PCR). In addition, a viral throat culture was performed and blood was drawn for viral serologies (see below). Two days after admission, a papular (nonvesicular) rash was noted (Figure 1). The rash was mainly on the trunk but also involved proximal regions of the upper and lower limbs. Three days after admission, small vesicles were noted on the penis as well as throughout the oral cavity. There was no obvious gingivitis. Further questioning revealed that the patient had had genital and oro-genital relations (ie, the patient performed oral sex on the partners and vice versa) with two new female partners 10 days before onset of symptoms as well as sexual relation with his wife, two days before symptoms. To his knowledge, none of his partners had had labial or genital blisters recently. The viral throat culture collected on admission returned positive for HSV-1. Similarly, viral culture of the genital lesions and whole blood PCR collected three days after admission were also positive for HSV-1 and HSV-1 plus Epstein Barr virus (EBV), respectively, whereas plasma PCR was negative for herpes viruses. Serologies for HIV-1, cytomegalovirus (immunoglobulin ( $\mathrm{Ig}) \mathrm{M}$ ), toxoplasmosis (IgM), syphilis, parvovirus B19 (IgM), hepatitis A/B/C and HSV-1/2 (Focus HerpeSelect ELISA IgG) were all negative, whereas EBV viral capsid antigen and EBV nuclear antigen IgG tests

\footnotetext{
${ }^{1}$ Research Center in Infectious Diseases, Centre Hospitalier Universitaire de Québec; ${ }^{2}$ Laval University, Québec City; ${ }^{3}$ Microbiology and Immunology departments of Sainte-Justine Hospital and University of Montréal, Montréal, Quebec

Correspondence: Dr Guy Boivin, CHUQ (CHUL), Room RC-709, 2705 Laurier Boulevard, Québec City, Quebec G1V 4G2.

Telephone 418-654-2705, fax 418-654-2715, e-mail Guy.Boivin@crchul.ulaval.ca
} 


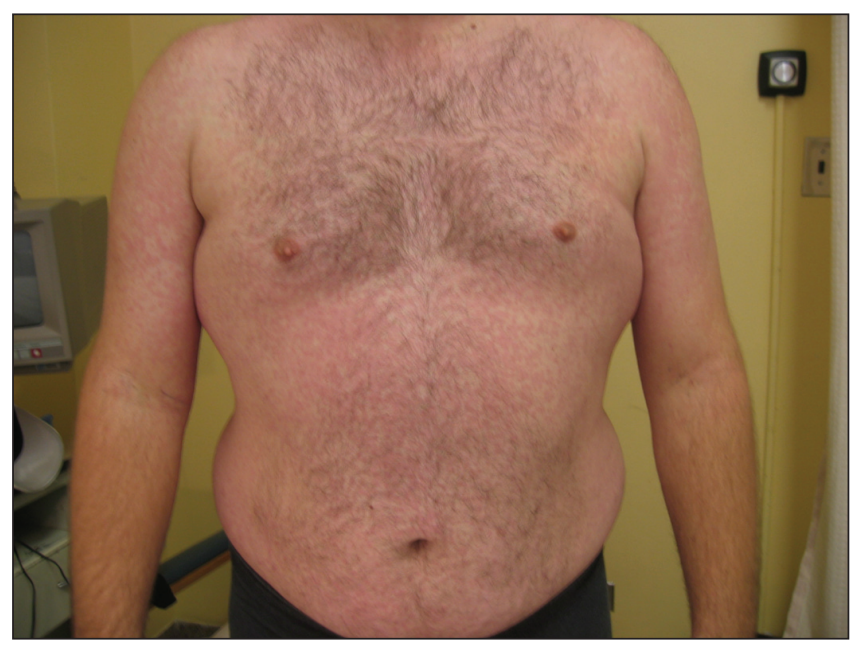

Figure 1) Papular rash associated with a disseminated primary herpes simplex virus type 1 infection in a healthy man

were both positive. In addition, all blood, urine and throat (including $\mathrm{N}$ gonorrhoeae) bacterial cultures as well as urine PCR for $\mathrm{C}$ trachomatis and $\mathrm{N}$ gonorrhoeae returned negative. The patient received two days of intravenous acyclovir $(5 \mathrm{mg} / \mathrm{kg}$ every $8 \mathrm{~h}$ ) followed by eight days of oral valacyclovir ( $1000 \mathrm{mg}$ twice daily) with rapid resolution of fever and rash. Hepatic transaminases returned to almost normal values within five days. He was discharged from the hospital after five days with a diagnosis of primary disseminated HSV-1 infection.

At a follow-up visit three weeks later, the patient was afebrile with no rash and no vesicles in the oral and genital areas. The serology for HIV-1 remained negative but the serology for HSV-1 was now positive (optical density $=1.33$, cut off greater than 0.32). One year after admission, the patient denied any recurrences of oral and genital lesions and the HIV-1 serology was still negative.

\section{METHODS}

Viral cultures for HSV were performed by inoculating throat and genital swabs on a series of tertiary cell lines in 96-well plates including mink lung, foreskin fibroblast, A549, Vero, HEp2, RD, 293 and HT29 cells. Cytopathic effects were confirmed by type-specific antibodies (Patho Dx). Viral DNA was extracted from whole blood using the QIAamp DNA Blood Extraction Mini Kit (Qiagen, Canada). Amplification of viral DNA was initially done by using consensus DNA polymerase primers for herpesviruses (HSV-1, HSV-2, EBV, cytomegalovirus) followed by restriction enzyme analysis with BamH1 and BstU1 as previously reported (1). The HSV-1 DNA load in whole blood was also quantified by real-time PCR with adjacent fluorogenic probes (2). Genotyping of oral and genital HSV-1 strains was based on PCR amplification of genes coding for glycoproteins I (gI), E (gE) and G (gG) followed by DNA sequencing using previously described primers and protocols $(3,4)$. Two separate amplicons for each viral strain were used for genotypic studies. Viral sequences of the patient and other clinical and laboratory HSV-1 strains were aligned with the ClustalW program. Phylogenetic analyses were conducted with the Molecular Evolutionary Genetics Analysis version 4 (USA) software using neighbour-joining algorithm with Kimura-2 parameters (5).

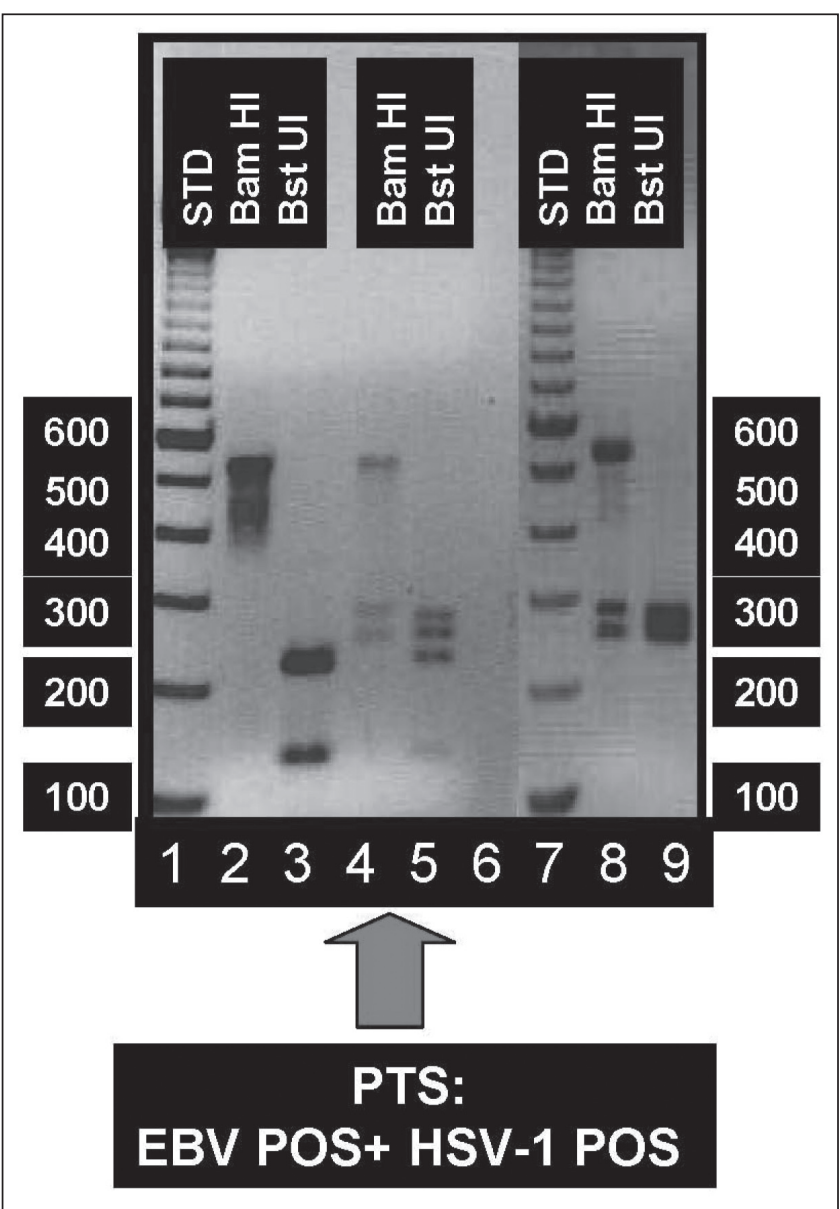

Figure 2) Restriction enzyme digestion pattern of herpesvirus DNA polymerase gene. Digestion reaction mixtures (BamH1 and Bst $U 1$ ) were electrophoresed on 1.5\% agarose gel. Lanes 1 and 7:100-bp DNA ladder; lanes 2 and 3: Epstein Barr virus B95-8 strain DNA; lanes 4 and 5: patient blood DNA sample; lanes 8 and 9: herpes simplex virus type 1 MacIntyre strain DNA

\section{RESULTS}

Whole blood qualitative PCR for herpesviruses revealed the presence of HSV-1 and EBV as confirmed by restriction enzyme analysis with BamH1 and BstU1 (Figure 2). The amount of HSV-1 DNA was subsequently quantified by real-time PCR and the blood HSV-1 load was estimated at 195 copies/mL (data not shown). Due to low viral load, it was impossible to determine the genotype of the blood HSV-1 strain. Both oral and genital HSV isolates grew in two days on Vero and A549 cells. Genotyping of the oral and genital HSV-1 strains was successfully performed based on variable regions of three glycoprotein genes. As shown in Figures 3A to 3C, both amplicons from the same strain and both strains had identical sequences for $\mathrm{gG}, \mathrm{gE}$ and $\mathrm{gI}$ genes. These sequences were clearly different from those of other clinical and laboratory (HSV 17) strains.

\section{DISCUSSION}

The simultaneous involvement of two different mucosal sites by the same virus during primary HSV infection has been reported in a small series of subjects by Lafferty et al (6). However, in the latter study, the presence of viremia was not 


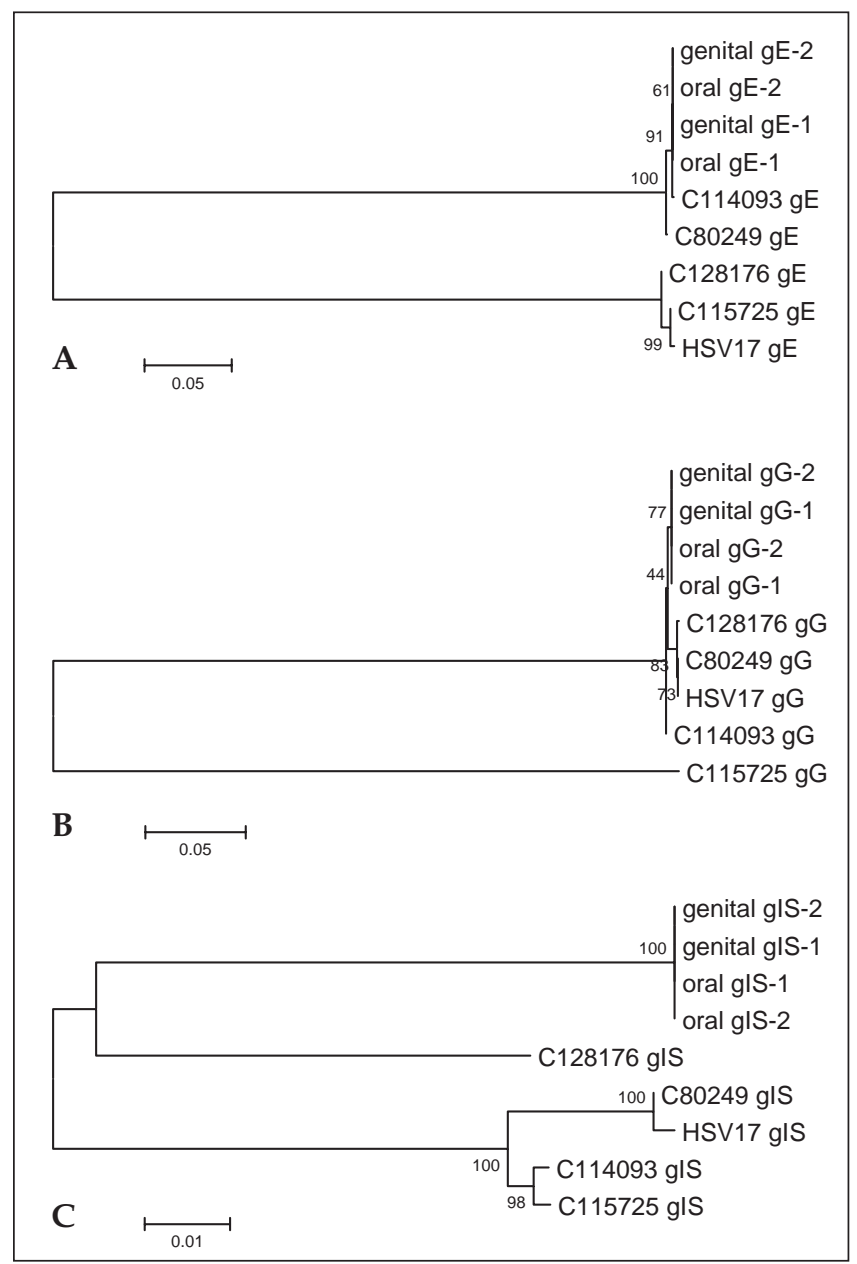

Figure 3) Phylogenetic analyses of the herpes simplex virus type 1 (HSV-1) glycoprotein (g) E (A), G (B) and I (C) genes. The evolutionary histories were inferred using the Neighbor Joining method. The evolutionary distances were computed using the Kimura 2-parameter method and are in units of the number of base substitutions per site. Two amplicons per patient mucosal site (oral and genital) were sequenced and aligned. Other clinical HSV-1 isolates (identified by the letter C) and a laboratory strain (HSV 17) are also included in the tree

documented and the HIV serological status was not systematically assessed. During reactivation episodes, HSV-2 (and HSV-1) shedding from both genital and orolabial sites has been reported in men having sex with men, suggesting that the same virus can potentially establish latency in two different ganglia (7). Our genotypic analysis unequivocally showed that our patient was infected by a single HSV-1 strain despite the fact

\section{REFERENCES}

1. Johnson G, Nelson S, Petric M, Tellier R. Comprehensive PCRbased assay for detection and species identification of human herpesviruses. J Clin Microbiol 2000;38:3274-9.

2. Boivin G, Goyette N, Sergerie Y, Keays S, Booth T. Longitudinal evaluation of herpes simplex virus DNA load during episodes of herpes labialis. J Clin Virol 2006;37:248-51.

3. Norberg P, Bergstrom T, Rekabdar E, Lindh M, Liljeqvist JA. Phylogenetic analysis of clinical herpes simplex virus type 1 isolates identified three genetic groups and recombinant viruses. J Virol 2004;78:10755-64. he had had multiple sexual partners within the last 10 days before onset of symptoms. Since he denied any recurrences one year after primary infection, and considering that shedding studies were not performed, we cannot speculate on the possible site(s) of HSV latency.

HSV viremia has been typically reported in immunocompromised hosts $(8,9)$ and in cases of neonatal HSV infections (10). More recently, with the advent of sensitive detection methods such as PCR, HSV viremia has been reported in 24\% of immunocompetent subjects with primary genital HSV (mainly women with HSV-2 infection) (11). Similarly, HSV DNA in the blood has been detected in 34\% of children with primary herpetic gingivostomatitis (12) and even in healthy patients with recurrences of herpes labialis (13). Our case report indicates that HSV viremia was of low grade (less than 200 copies $/ \mathrm{mL}$ ) with positivity documented in whole blood but not in plasma. Other groups have found higher levels of viral DNA as well as encapsulated HSV DNA in plasma of immunocompetent subjects, although they could not confirm the presence of infectious virions by culture (11). Additional studies are warranted to establish the peak and duration of viremia relative to onset of symptoms and the exact blood compartment where HSV replicates.

An unusual feature of our case was the presence of a nonvesicular, papular disseminated rash (Figure 1). Most previously reported cases of HSV-related eruptions, whether in the case of eczema herpeticum or in immunocompromised hosts or pregnant women, have been predominantly vesicular $(14,15)$. We believe that our patient's rash was related to his primary disseminated HSV infection due to concomitant HSV viremia. However, we cannot exclude a drug-related eruption (levofloxacin was stopped two days before rash onset) or an EBVassociated rash with hepatitis (EBV DNA was found in the blood but the mononucleosis test was negative and specific serological results indicated a past infection).

\section{CONCLUSION}

Our case report adds significant new knowledge that could be helpful in understanding the pathogenesis of primary HSV infection in modern age virology. Although additional prospective studies are needed, our results suggest that prior HSV dogmas (ie, localized and compartmentalized infection by a single viral type in immunocompetent subjects) should be revisited. Importantly, whether simultaneous infection of both oral and genital mucosal sites can occur or whether viremia contributes to inoculation of a second mucosal site needs further study.

ACKNOWLEDGEMENTS: No financial support was provided for this study. None of the authors has a conflict of interest.

4. Rekabdar E, Tunback P, Liljeqvist JA, Bergstrom T. Variability of the glycoprotein $G$ gene in clinical isolates of herpes simplex virus type 1. Clin Diagn Lab Immunol 1999;6:826-31.

5. Kumar S, Tamura K, Nei M. MEGA3: Integrated software for Molecular Evolutionary Genetics Analysis and sequence alignment. Brief Bioinform 2004;5:150-63.

6. Lafferty WE, Coombs RW, Benedetti J, Critchlow C, Corey L. Recurrences after oral and genital herpes simplex virus infection. Influence of site of infection and viral type. N Engl J Med 1987;316:1444-9. 
7. Kim HN, Meier A, Huang ML, et al. Oral herpes simplex virus type 2 reactivation in HIV-positive and -negative men. J Infect Dis 2006;194:420-7.

8. Stanberry LR, Floyd-Reising SA, Connelly BL, et al. Herpes simplex viremia: report of eight pediatric cases and review of the literature. Clin Infect Dis 1994;18:401-7.

9. Naraqi S, Jackson GG, Jonasson OM. Viremia with herpes simplex type 1 in adults. Four nonfatal cases, one with features of chicken pox. Ann Intern Med 1976;85:165-9.

10. Diamond C, Mohan K, Hobson A, Frenkel L, Corey L. Viremia in neonatal herpes simplex virus infections. Pediatr Infect Dis J 1999; 18:487-9.

11. Johnston C, Magaret A, Selke S, Remington M, Corey L, Wald A. Herpes simplex virus viremia during primary genital infection. J Infect Dis 2008;198:31-4.
12. Harel L, Smetana Z, Prais D, et al. Presence of viremia in patients with primary herpetic gingivostomatitis. Clin Infect Dis 2004;39:636-40.

13. Youssef R, Shaker O, Sobeih S, Mashaly H, Mostafa WZ. Detection of herpes simplex virus DNA in serum and oral secretions during acute recurrent herpes labialis. J Dermatol 2002;29:404-10.

14. Frederick DM, Bland D, Gollin Y. Fatal disseminated herpes simplex virus infection in a previously healthy pregnant woman. A case report. J Reprod Med 2002;47:591-6.

15. Justice EA, Khan SY, Logan S, Jobanputra P. Disseminated cutaneous herpes simplex virus-1 in a woman with rheumatoid arthritis receiving infliximab: A case report. J Med Case Reports 2008;2:282. 


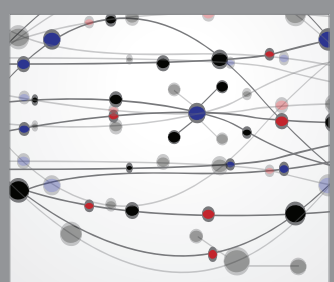

The Scientific World Journal
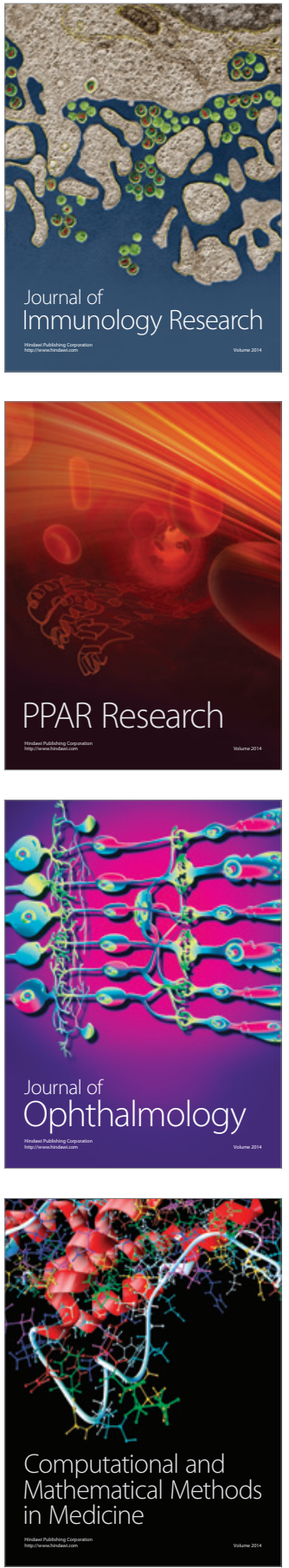

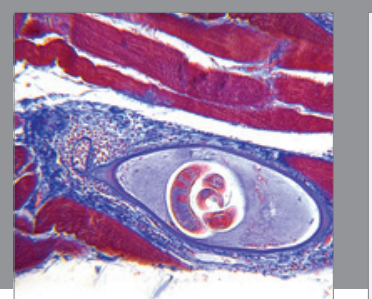

Gastroenterology Research and Practice

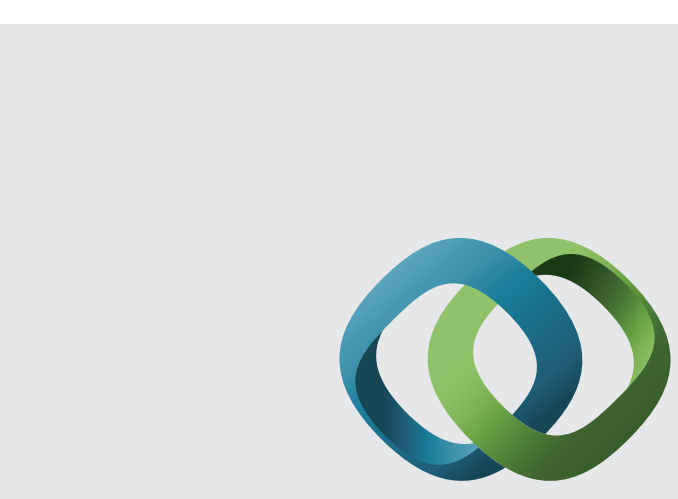

\section{Hindawi}

Submit your manuscripts at

http://www.hindawi.com
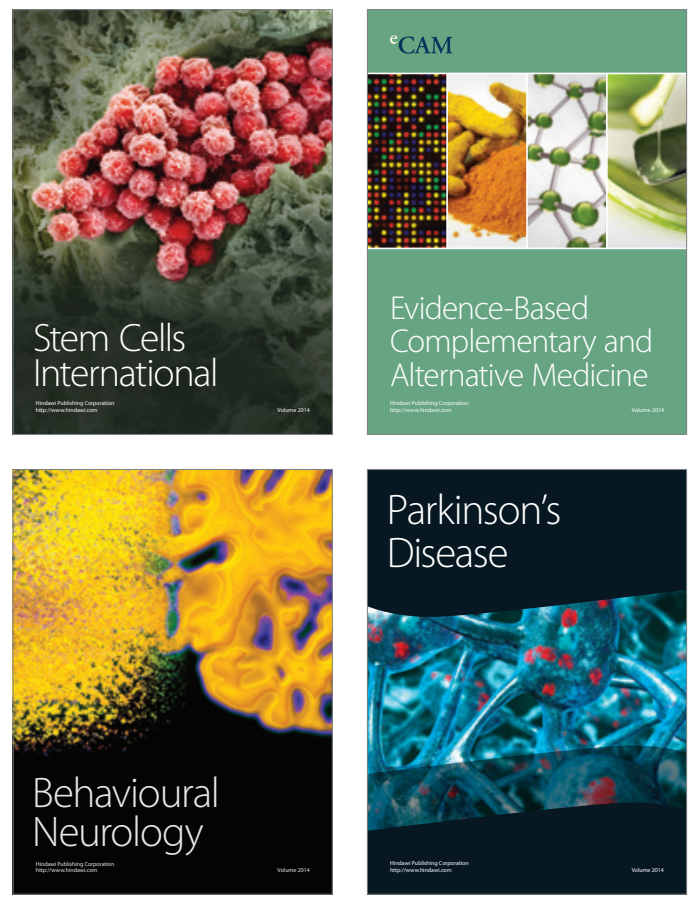
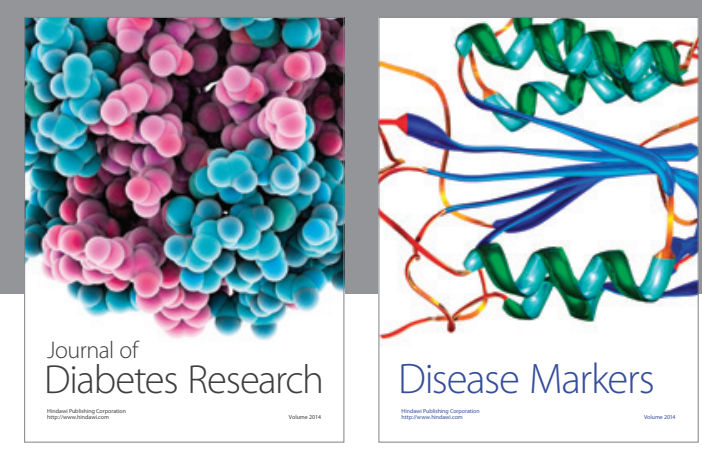

Disease Markers
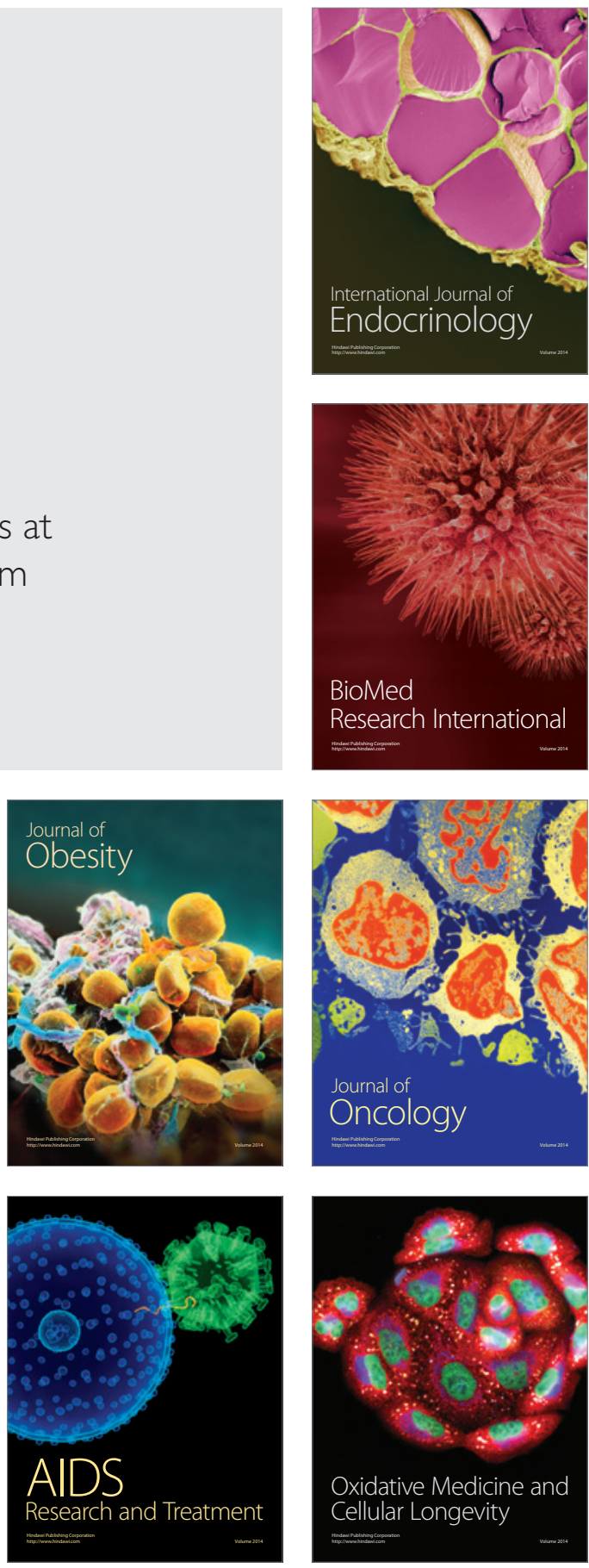